\title{
The United States' National Interests and the Fight Against Boko Haram Terrorism in Nigeria
}

\author{
Michael I. Ugwueze \\ Department of Political Science, University of Nigeria, Nsukka, Nigeria \\ michael.ugwueze@unn.edu.ng \\ Vincent C. Onah \\ Department of Political Science, University of Nigeria, Nsukka, Nigeria \\ vincent.onah@unn.edu.ng

\section{Chikodiri Nwangwu} \\ Department of Political Science, University of Nigeria, Nsukka, Nigeria \\ chikodiri.nwangwu@unn.edu.ng
}

Doi:10.5901/mjss.2016.v7n3s1p478

\section{Abstract}

\begin{abstract}
The study was an attempt aimed at understanding the relationship between the United States national interests in Nigeria and the fight against Boko Haram terrorism. It raised the pertinent question of why the United States is involved in the fight against Boko Haram terrorism. Using a qualitative approach, the study discovered that the United States national interests remain largely unchanged and its averred condemnation of foreign terrorism incontestable, and therefore, responsible for its involvement in the fight against Boko Haram terrorism. However, since the designation of the group as Foreign Terrorist Organization (FTO) by the United States, its members appear more determined, ferocious and coordinated in their attacks against the Nigerian state. To this end, the work recommended that the global community should see the fight against Boko Haram scourge from the prism of international terrorism and thereby contribute immensely to arrest it.
\end{abstract}

Keywords: United States, national interests, terrorism, boko haram

\section{Introduction}

The United States' national interest in Nigeria has increasingly remained consistent over the years and it appears that not even the Boko Haram insurgence can significantly change it. However, to underrate the possibility of Boko Haram insurgence significantly affecting the United States interests in Nigeria due largely to the concentration of the sect's activities in the North-Eastern part of the country is to undermine the capability of the group's impact on the security of both countries. Against this backdrop, many analysts have drawn the attention of the United States government in assisting Nigeria in finding a lasting solution to the problem posed by the group (Ham, 2012; Oritsejafor, 2012; Campbell, 2012 and Meehan, 2012).

Consequently, Boko Haram, properly called Jama'atu Ahlis Sunna Lidda'awati Wal Jihad, meaning "people committed to the propagation of the Prophet's teachings and Jihad" has undoubtedly appeared to pose serious security threat to the governments of both the United States and Nigeria. Its leader Abubakar Shakau has continually threatened that the moment they were through with the Nigerian government, their next target would be the United States, seen to be the leading agent in the propagation of the western values (boko) which the sect considers to be sin (haram). Notwithstanding this threat, the government of the United State has hitherto seen the group not to possess the magic wands necessary to make real its threats. However, given the successful execution of the group's terrorist acts within and outside the shores of Nigeria, including the kidnapping of foreign expatriates in Cameroon and Niger Republic, the United States government appears to be faced bare with the realities on ground and the capability of the sect in carrying out its threats; hence, the recent designation as Foreign Terrorist Organization.

Meanwhile, the Boko Haram sect ab initio made its stand known and subsequently adopted violent philosophy in pursuit of its goals whereas the United States continued to underplay the activities of the group as a mere expression of 
grievances against the Nigerian state by the members until recently when it became clear to the country that such assumption was wrong. This necessitated open commitment of the American government in finding a lasting solution to the Boko Haram crisis in Nigeria by way of labeling the sect Foreign Terrorist Organization. However, it does appear that since this designation, the sect has become more determined and ferocious in their attacks than before. More than one thousand five hundred (1500) deaths have been recorded within the period alone (Amnesty International, 2014 and Bekele, 2014) in addition to the abduction of over 200 school girls at Chibok, Borno state. The study therefore aims to understand the relationship between the United States' national interests in Nigeria and its involvement in the fight against Boko Haram terrorism.

Methodologically, the study is specifically a qualitative one which relies mostly on documentary evidence and generation of tables for lucid clarification of data as well as the understanding of the argument.

\section{The United States' National Interest in Nigeria and the Fight Against Boko Haram}

The US national interest in Nigeria can be summarized as follows:

- Stable democracy with business friendly environment

- Free flow of crude oil

- Partnership for the maintenance of regional peace and security.

Due largely to the fact that the focus of the study is not on the first two, we shall therefore deal with only the US partnership with Nigeria in the maintenance of regional peace and security which has implication on the fight against Boko Haram terrorism.

It is absolutely undisputable that Nigeria is a regional power and therefore indispensable by the United States for the maintenance of regional peace and security. Nigeria has contributed immensely in peacekeeping missions around the world; both under the auspices of the UN, AU and ECOWAS. Some of these peacekeeping missions include: Cong, Sierra Leone, Sudan, among others, and in each of these, Nigeria had excelled as a regional power (Sanda, 2010). Indeed, Jega and Farris (2010: 231) have observed that:

Peacekeeping, peace building, peace enforcement, and peace-support operations constitute a major area of achievement in Nigeria's involvement in global affairs. Beginning with participation in the UN Mission in the Congo (19601964) to its foray in Chad (1979-1982); through its contributions to UN missions in Lebanon (1978-1981) and BosniaHerzegovina (1992-1995); its involvement with African Union (AU) missions in Darfur, Sudan (since, 2004); and its leadership in the Economic Community of West African States (ECOWAS) through the Economic Community of West African States Monitoring Group (ECOMOG) operations in Liberia (1990-1998) and Sierra Leone (1996-2000), as well as its interventions in Guinea Bissau (1998-2000) and Cote d'Ivoire (since, 2000), Nigeria has helped to contain conflicts, minimize suffering, restore order, reconstruct war-torn societies, and pave the way for transitions to civil rule and democratization.

Due largely to these crucial roles, the US cannot afford to lose sight of this gigantic edifice called Nigeria to insurgence thereby creating lacuna in those areas the country had excelled. In view of the foregoing, the former Vice President of Nigeria, Alhaji Atiku Abubakar, in his address at the University of California, Los Angeles, persuading the US that in the emerging New World Order, the destiny of Nigeria and the US are irrevocably intertwined, observed as follows:

... may I remark that in a rather ironic twist of historical fate, it has been over a century America's lot to critically influence the course of world history. This cannot be totally divorced from its population, size, resource potentials and profile as an established democracy. Nigeria's population, size, resource potentials and leadership profile within the comity of Africa's emerging democracies also set her apart. Thus, while Nigeria is transiting from age-old military dictatorship into the realm of civilian democracy, the world is also transiting into a new international order. For Nigeria's transition to succeed, collaboration with the international community is vital; and for the current transition to new world order to succeed, the cooperation of emerging democracies is imperative. Nigeria and the United States therefore carry the dreams of the people of the earth and hence hold a significant stake in shaping the destiny of our evolving new world order. We cannot afford to fail; we should not even contemplate the possibilities of failure. Nigeria stands prepared to play its part. But because every chain is as strong as its weakest link. America must share its strength with Nigeria in this regard so that together we can live the promise of our vision of a better world (cited in Adogamhe, 2006: 113).

However, the partnership with Nigeria for the pursuit and maintenance of regional peace and security by the United States appears incontestable. Another benefit that accrues to the US government from this partnership is reduction in the financial resources necessary to maintain peace and security around the world especially within Africa.

Having understood the basis of the United States' national interest in Nigeria especially as it affects this work, it is important to relate its foreign policy thrust to the fight against Boko Haram terrorism not only Nigeria but also in the West 
African sub region.

Since the notorious 9/11 attacks on the United States twin towers (Pentagon and World Trade Center), the country's foreign policy to international terrorism assumed a new shape. This new development involves taking the fight against terrorism to the host country instead of waiting until the terrorist activities get to the US soil. The 9/11 attacks also strengthened the US fight against terrorism. Against this backdrop, it is important to understand what terrorism is all about, at least, in the context of this study. Terrorism has been identified as a foreign policy issue, as well as a national Security issue (Pillar, 2001: 9). Deriving from the above, Pillar remarked that:

Most of the terrorism that has damaged US interest is foreign, as are most of the significant terrorist threats that confront the United States today. Seventy-eight percent of the Americans who died from terrorism during the past two decades were killed by foreign terrorists (Pillar, 2001: 9).

Terrorism itself has elicited unquantifiable definitional wrangles that have combined to compound its meaning. However, Pillar (2001: 13) has identified four main elements that distinguish terrorism from other acts of violence. These elements include:

1. Premeditation: this means that there must be an intent and prior decision to commit an act that would qualify as terrorism under the other criteria. An operation may not be executed as intended and may fail altogether, but the intent must still be there. Terrorism is not a matter of momentary rage or impulse or even a matter of accident.

2. Political Motivation: terrorism excludes criminal violence motivated by monetary gain or personal vengeance except if such has direct bearing to the implementation of the terrorists' objectives. Nevertheless, other forms of criminal violence have been tagged terrorism but the fundamental difference between terrorism and other forms of crime or criminal violence lies in the onus of what gives rise to it and how it must be countered, beyond simple physical security and police techniques. What terrorists have in common that separates them from other violent criminals is that they claim to be serving some greater good.

3. The targets are non-combatant groups: this suggests that terrorists attack people who cannot defend themselves with violence in return.

4. The perpetrators are either sub-national groups or clandestine agents.

Terrorism in this context therefore means premeditated, politically motivated violence perpetrated against noncombatant targets by sub-national groups or clandestine agents, usually intended to influence an audience. Any act of violence that meets these criteria could be tagged Terrorism.

Consequent upon the foregoing, the US interest in maintaining zero tolerance to international terrorism gave rise to the establishment of section 219 of the Immigration and Nationality Act (INA) 2001 as amended which empowers the US Secretary of State with the approval of the President to label any violent group(s) found to be involved in terrorist activities outside the United States, Foreign Terrorist Organization (FTO). For a group to be qualified as a terrorist organization, it must possess the following:

1. The group must be domiciled in a foreign country (that is, outside the US territory).

2. The group must be involved in terrorist activity(ies).

3. Such activity(ies) must be a threat to the United States security (http://www.state.gov/j/ct/rls/other/des/ 123085.htm).

FTO designation plays critical role in the US fight against terrorism and it is an effective means of curtailing support for terrorist activities and pressuring groups to get out of the terrorism business. Foreign, as explained earlier, refers to non-United States based organization and most of the organizations as at 2014 have been mostly Islamic extremist groups; with the remaining largely Communist and nationalist/separatist groups. For the sake of emphasis, the table below shows some of the Foreign Terrorist Organizations around the world which includes Boko Haram and their host countries.

Table 2: List of Foreign Terrorist Organizations around the World

\begin{tabular}{|c|l|c|l|}
\hline S/N & FTO & Other Names Called & Host countries \\
\hline 1 & Abu Nidal Organization & ANO & Palestine \\
\hline 2 & Al-Aqsa Martyr's Brigades & & Palestine \\
\hline 3 & Islamic Resistance Movement & Hamas & Palestine \\
\hline 4 & Army of Islam & - & Palestine \\
\hline 5 & Islamic Jihad Group & - & Palestine \\
\hline 6 & Palestine Liberation Front & PLF & Palestine \\
\hline 7 & Popular Front for the Liberation of Palestine & PFLP & Palestine \\
\hline
\end{tabular}




\begin{tabular}{|c|c|c|c|}
\hline & PFLP-General Command & PFLP-GC & Palestine \\
\hline 9 & Al-Qaeda Kurdish Battalions (formerly Ansar al-Islam) & - & Iraqi Kurdish \\
\hline 10 & Kata'ib Hezbolah & - & Iraq \\
\hline 11 & Kongra-Gel (formerly Kurdistan Workers Party) & KGK, formerly PKK, KADEK & Turkey, Iraq, Iran and Syria \\
\hline 12 & $\begin{array}{l}\text { Tanzim Qa'idat al-Jihad al-Rafidayn (formerly Jama'at al- } \\
\text { Tawhid Wa'al Jihad or al-Zarqawi Network) }\end{array}$ & $\begin{array}{l}\text { QSBR or JTJ or al-Qaida in } \\
\text { Iraq }\end{array}$ & Iraq \\
\hline 13 & Asbat an-Ansar & - & Lebanon \\
\hline 14 & Party of God & Hezbollah & Lebanon \\
\hline 15 & Kahane Chai & Kach & Israel \\
\hline 16 & Mujahedin-e Khalq Organization & MEK & Iran \\
\hline 17 & People's Resistance Movement of Iran & PRMI or Jundallah & Iran \\
\hline 18 & Al-Qaeda & - & Global \\
\hline 19 & Al-Qaeda in the Arabian Peninsula & AQAP & Arabian Peninsula \\
\hline 20 & Al-Qaeda in the Islamic Maghreb & AQIM & Maghreb \\
\hline 21 & Haqqani Network & - & Bangladesh \\
\hline 22 & Harkat-ul-Jihad al-Islamic & Huji-B & Bangladesh \\
\hline 23 & Liberation Tigers of Tamil Eelam & LTTE & Sri Lanka \\
\hline 24 & Indian Mujahideen & IM & India \\
\hline 25 & Aum Shinrikyo & - & Japan \\
\hline 26 & Harakat ul-Mujahidin & HUM & Pakistan \\
\hline 27 & Jaish-e-Mohammed & JEM & Pakistan \\
\hline 28 & Lashkar-e Tayyiba (Army of the Righteous) & LET & Muridke and Pakistan \\
\hline 29 & Lashkar I Jhangvi & - & Pakistan \\
\hline 30 & Tehrik-i-Taliban Pakistan & TTP & Pakistan \\
\hline 31 & Jemaah Islamiya Organization & $\mathrm{J}$ & $\begin{array}{l}\text { Brunci, Indonesia, Malaysia, Thailand } \\
\text { Philippines and Singapore }\end{array}$ \\
\hline 32 & Abu Sayyaf Group & ASP & Philippines \\
\hline 33 & Communist Party of the Philippines (New People's Army) & CCP (NPA) & Philippines \\
\hline 34 & Islamic Movement of Uzbekistan & IMU & Uzbekistan \\
\hline 35 & Al-Shabaab & - & Somalia \\
\hline 36 & Armed Islamic Group & GIA & Algeria \\
\hline 37 & Gama'a al-Islamiyya & - & Egypt \\
\hline 38 & Libyan Islamic Fighting Group & LIFG & Libya \\
\hline 39 & Lord's Resistance Army & - & Uganda \\
\hline 40 & Moroccan Islamic Combatant Group & MICG & Morocco \\
\hline 41 & Continuity Irish Republican Army & CIRA & UK and Republic of Ireland \\
\hline 42 & Real Irish Republican Army & RIRA & UK and Republic of Ireland \\
\hline 43 & Ulster Volunteer Force & UVF & UK and the Republic of Ireland \\
\hline 44 & Ulster Defense Association & UDA & UK and the Republic of Ireland \\
\hline 45 & Revolutionary Organization 17 November & - & Greece \\
\hline 46 & Revolutionary Struggle & - & Greece \\
\hline 47 & Revolutionary People's Liberation Party/Front & DHKP/C & Turkey \\
\hline 48 & Kurdistan Workers Party & PKK & Turkey \\
\hline 49 & Euskadi Ta Askatasuna (Basque Fatherland and Liberty) & ETA & Spain and France \\
\hline 50 & National Liberation Army & ELN & Colombia \\
\hline 51 & Revolutionary Armed Forces of Colombia & FARC & Colombia \\
\hline 52 & United Self-Defense Forces of Colombia & AUC & Colombia \\
\hline 53 & Shining Path (Sendro Luminoso) & $\mathrm{SL}$ & Peru \\
\hline 54 & Jamaah Ansharut Tauhid & JAT & Indonesia \\
\hline 55 & Abdullah Azzam Brigades & - & Iraq \\
\hline 56 & Ansar Dine & - & Mali \\
\hline 57 & Boko Haram & $\begin{array}{l}\text { Jama'atu Ahlis Sunna } \\
\text { Lidda'awati Wal Jihad }\end{array}$ & Nigeria \\
\hline 58 & Ansaru & - & Nigeria \\
\hline 59 & Al-Mulathamun Brigade & - & Algeria \\
\hline 60 & Ansar al-Sharia in Benghazi & - & Libya \\
\hline 61 & Ansar al-Sharia in Darnah & - & Libya \\
\hline 62 & Ansar al-Sharia in Tunisia & - & Tunisia \\
\hline 63 & Ansar Bayt al-Maqdis & - & Egypt \\
\hline
\end{tabular}

Source: http://en.wikipedia.org/wiki/U.S._State_Department_list_of_foreign_Terrorist_Organizations, retrieved on $4^{\text {th }}$ June, 2014 
Let us state therefore that what is called Foreign Terrorist Organization is what the United States says it is. The names by which they are called are the names they were designated with by the United States.

Besides the above condition for designating a group foreign terrorist organization, the Office of the Coordinator for Counterterrorism (S/CT) in the US State Department must look not only at the actual terrorist attacks that a group has carried out, but also at whether the group has engaged in planning and preparations for possible future acts of terrorism or retains the capability and intent to carry out such acts (http://en.wikipedia.org/wiki/U.S._State_Department_list_ of_foreign_Terrorist_Organizations). Once a group has been so identified, the Office of the Coordinator for Counterterrorism prepares a detailed administrative record, which is a compilation of information, typically including both classified and open sources information, demonstrating that the statutory criteria for designation have been satisfied. If the Secretary of State, in consultation with the Attorney General and the Secretary of the Treasury, decides to make the designation, then the US Congress is notified of the Secretary's intent to designate the organization and given seven days to review the designation, as the Immigration and Nationality Act (INA) requires (see section 219 of the INA in the 2001 USA PATRIOT Act and also retrievable from http://en.wikipedia.org/wiki/U.S._State_Department_list_of_foreign_ Terrorist_Organizations). The INA provides that, upon the expiration of the seven-day waiting period, notice of the designation is published in the Federal Register, at which point the designation takes effect. However, an organization designated as an FTO may seek judicial review of the designation in the United States Court of Appeals for the District of Columbia Circuit not later than 30 days after the designation is published in the Federal Register.

In line with this, the US government on November 24, 2013 considered Boko Haram a foreign terrorist organization having met the above qualities of a terrorist group. The figure represents the concentration of Boko Haram attacks in Nigeria since 2009.

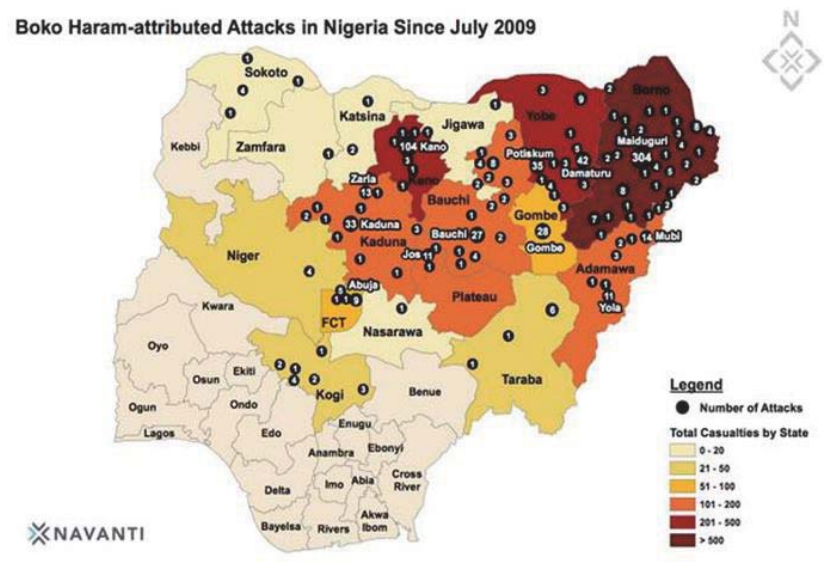

Source: http://www.trackingterrorism.org/group/boko-haram

The choice of the figure was due largely to the constant nature of Boko Haram attacks which has virtually made it impossible to summarize the information in a table especially between 24 $4^{\text {th }}$ November, 2013 (when the sect was designated an FTO) and August 2015. Accordingly, the African director of the United Nations Office for the Coordination of Humanitarian Assistance (UNOCHA), Daniel Bekele, observed that:

Boko Haram attacks have increased during the first two months of 2014, with almost daily killings, bombings, theft, and the destruction of schools, homes, and businesses in north-eastern Nigeria villages. These assaults have led to the death of (over) 700 people, the abduction of (over) 25 women and girls, and the mass displacement of residents (http://www.hrw.org/news/2014/03/14/nigeria-boko-haram-attacks-cause-humanitarian-crisis).

As a corollary, Amnesty International also said that more than 1,500 people were killed during 2014 alone in an escalating armed conflict between Boko Haram insurgents and the Nigerian security forces and that more than half of these victims were civilians (http://voanews.com/a/amnesty-1500-nigerians-killed-in-boko-haram-violence-in-2014/1883187.html. Summarily, over seventeen thousand lives have been lost and property worth billion of Naira destroyed since the Boko Haram insurgence in Nigeria.

In fact, what remains the problem is that since the designation of Boko Haram sect as Foreign Terrorist 
Organization, the group has become more coordinated, ferocious and determined in their attacks against the people and constituted authorities in Nigeria. The impression being created is that the US involvement in the fight against Boko Haram insurgence by extension means its averred declaration of interest in Nigeria and by implication means more attacks against the Nigerian state by the Boko Haram insurgents due to their hatred of the West and their ideologies which the United States represents. To the insurgents, since their activities in Nigeria constitute serious concern to the United States, it then means that the more they attack the former, the more the latter is affected. This can be taken to be the reason for the increasing coordinated, ferocious and determined attacks by the sect, as well as its identification with Islamic State of Iraq and al-Sham (ISIS). As at 2015, ISIS has remained a foremost enemy of the West and the leading terrorist organization in the world.

\section{Conclusion}

The increasing security threat of Boko Haram insurgence has become a source of concern to many countries especially the United States; hence, its involvement in finding a lasting solution to the crisis. However, it appears that since the United States indicated interest in the fight against the scourge through the designation of the group as a foreign terrorist organization on $24^{\text {th }}$ November, 2013 , the sect appears to be more coordinated and determined in its violent campaign against the Nigerian states with serious pockets of influence within the West African sub region. The height of this insurgency remains the abduction of over 200 school girls at Chibok, Borno state which has attracted global condemnation.

In a nutshell, the study attempted to understand the United States national interest and its relationship in the fight against Boko Haram terrorism in Nigeria which is increasingly becoming sarcastically melodramatic. This was done through the exploration of the US national interests in Nigeria which can be summarized as follows: stable democracy, trade and investment as well as maintenance of regional peace and security for a free-flow of crude oil. A threat to any of these would be met with stiff resistance by the United States government especially if such threat has the capability of producing far-reaching consequence(s) to the free-flow of crude oil from the Gulf of Guinea. Against this backdrop, the continued attacks against the Nigerian state by the Boko Haram insurgents remain a large threat not only to security of Nigeria but the entire West African sub region. Hence, for the United States to remain aloof to this dangerous trend is akin to bargaining with the devil (international terrorist groups) for goods and services whose only value is production of regional and global insecurity.

Finally, it is important to state here that while direct US involvement in the fight against Boko Haram insurgence may not be a good omen for Nigeria, it has become a necessary and unavoidable evil especially as the fight against terrorism needs more coordinated support from countries well-equipped technologically which sometimes might be a necessary ingredient for breaching national sovereignty. To this end therefore, it is important for the international community (not just the United States) to see the fight against Boko Haram terrorism as a collective fight against international terrorism and make effort towards arresting the scourge.

\section{References}

Adefuye, A.I. (2012). Nigeria is America's Anchor in Africa. Tell, September 3.

Adefuye, A.I. (2013). Boko Haram and Alemieyeseigha: Effects on Nigeria-US Relations. Vanguard, March 18

Adogamhe, P.G. (2006). Rethinking the North/South Relations: An Analysis of the US/Nigerian Hegemonic Overtures. Nigerian Journal of International Affairs. 32 (1): 99-132

Agande, B. (2013). FG Faults US Claim on Insecurity. Vanguard, May 11

Agbese, P.O. (2000). The Politics of Stable Civil-Military Relations. http://www.india.seminar.com/2000/490/490\%20agbase.htm, sourced $3 / 4 / 13$

Agbo, A. (2011. Jonathan's Big Dilenma. Tell, August 1

Ajakaye, R. (2013). 60 Feared Dead in Nigeria after Fresh Boko Haram Attacks. http://www.aa.com.tr/en/news/214598--60-feared-dedin-fresh-boko-haram-attacks, retrieved, 15/8/2013

Ajani, N. (2012). Nigeria: A Nation Chaired by Insurgency. Vanguard, August 12

Ake, C. (1981). Political Economy of Africa. Nigeria: Longman Nigeria Plc

Akeregha, I. (2004). Rebel with a Cause, Insider Weekly, October 18

Amnesty International (2014). 1500 Nigerians Killed in Boko Haram Violence in 2014. http://voanews.com/a/amnesty-1500-nigerianskilled-in-boko-haram-violence-in-2014-/1883187.html. Retrieved 3rd April, 2014

Asobie, H.A. (2008) Africa and the Science of Power: of Vultures and Peacocks. Nsukka: Beans Express Ltd

Bekele, D. (2014). Nigeria Boko Haram Attacks cause Humanitarian Crisis. http://www.hrw.org/news/2014/03/14/nigeria-boko-haramattacks-cause-humanitarian-crisis. retrieved 3rd April, 2014 
Campbell, J. (2012). Why not to Designate Boko Haram a Foreign Terrorist Organization, http://ynaija.com/blog/2012/05/25/why-not-todesignate-boko-haram-a-foreign-terrorist, retrieved 3/4/13

Carson, J. (2012). How to Resolve the Boko Haram Insurgency. Vanguard, August 12

Doublegist.com (2013). The Negative Impact of Boko Haram Activities to Nigeria and Its Foreign Political Relation. http://www. doublegist.com/the-negative-impact..., retrieved, 10/7/2013

Edeh, H.C, Ogon, S.O. and Okpala, A.L. (2009). Myths or Realities of Global Terrorism: U.S. Pre-emptive/Unilateral Foreign Policy on Global Peace and Security (2001-2007), in A.M. Okolie (ed.) Contemporary Readings on Nigeria's External Relations: Issues, Perspectives and Challenges. Abakaliki: Willyrose and Appleseed Publishing Coy

Ekanem, S.A, Dada, J.A. and Ejue, B.J. (2012). Boko Haram and Amnesty: A PhiloLegal Appraisal. International Journal of Humanities and Social Science. 2 (4) 231-244

Enekwechi, C. (2013). US Meddlesomeness in Nigeria's Affairs. Vanguard, April 4

Garamone, J. (n.d). US, Nigeria Discuss Defense Cooperation. http://www.defense.gov/news/newsArticle.aspx?ID=45099, retrieved $3 / 4 / 13$

Gartenstein-Ross, D and Vassefi, T. (2012). Current US Policies Toward Nigeria's Boko Haram. http://gunpowderandlead.org/2012/06/ current-u-s-policies--toward-nigeria-boko-haram/, retrieved 27/04/2013

Gilpin, R. (1987) The Political Economy of International Relations. New Jersey: Princeton University Press

Heras, N.A. and Zenn, J. (2013). Boko Haram: Threatening West Africa? http://www.fairobserver.com/article/boko-haram-threateningwest-africa, retrieved, 12/8/2013

Iluyemi, V. (2013). US Sees Insurgency as Nigeria's Biggest Challenge to Development. http://www.worldstagegroup.com/worldstage new/index. php?active $=$ news\&newscid $=10106 \&$ catid $=4$, retrieved 16/8/2013

Jega, A.M. and Farris, J.W. (2010). Nigeria at Fifty: Contributions to Peace, Democracy and Development. Abuja: the Shehu Musa Yar'Adua Foundation

Johnson, J.B. and Joslyn, R.A. (1992). Political Science Research Methods. Delaware: CQ Press

Lantigua-Williams, J. (2012). Nigeria's Stability Critical to U.S. http://www.progressive.org/nigeria_stability_critical_to_u.s.html, retrieved $7 / 9 / 12$

Levan, C. (2012). US Profs to Clinton: Respond to Boko Haram with Diplomacy, Development and Demilitarization. http://carllevan.com/ 201205/boko-haram-letter-toclinton-from-scholars, retrieved 12/2/13

MacWilson, A.C. (1992). Hostage-Taking Terrorism: Incident-Response Strategy. London: Macmillan

Madunagu, E. (2011). Reflections on Nigerian Terrorism. Journal of Constitutional Development. 11 (4) 1-6

Maiangwa, B. and Uzodike, U.O. (2012). The Challenging Dynamics of Boko Haram Terrorism. http://studies.aljazeera.net/en/reports/ 2012/07/20127316859987337.htm, retrieved on 6/9/12

Marama, N. (2013). Boko Haram Sacks 19,000 Wheat, Rice Farmers in Borno. Vanguard, June 14

McCulley, T. (2013). US Investment in Nigeria Hits $\$ 5$ bn. Punch, November 7

Minter, W. (2012). US is Pushed to Label Nigeria's Boko Haram a Terrorist Group. http://www.mcclatchydc.com/2012/07/23/1513, retrieved 20/11/12

Mohammed, A.S. (2010). Nigeria, OPEC, and the Middle East. In A.M. Jega and J.W. Farris (eds.) Nigeria at Fifty: Contributions to Peace, Democracy and Development. Abuja: the Shehu Musa Yar'Adua Foundation

Mudasiru, S.O (2001). Understanding the Dimensions of the New Face of Terror: A Political Economy of African Terrorist Groups. Journal of Constitutional Development. 11 (4) 94-110

Nnoli, O. (2006). National Security in Africa: A Radical New Perspective. Enugu: Snaap Press Ltd

Odoh, S.I. (2008). Oil Politics and Nigeria-United States Relations, 1999-2007. A Ph.D Thesis Submitted to the Department of Political Science, University of Nigeria, Nsukka.

Odunsi, W. (2012). Insecurity: US Advise Citizens to Avoid 21 States in Nigeria. http://dailypost.com.ng/2013/06/06/isecurity..., retrieved, $10 / 7 / 2013$

Ogban-Iyam, O. (2005). Social Production and Reproduction, Societal Conflicts and the Challenges of Democracy in Nigeria. University of Nigeria Journal of Political Economy. 1(1): 1-51

Ogirai, J.C. (2005). The United Nations and the Management of International Terrorism: The Case of Libya. A Ph.D Thesis Submitted to the Department of Political Science, University of Nigeria, Nsukka.

Okocha, C. (2013). Presidency: Nigeria, US Relations Cordial. Thisday, April 3

Okoye, E. (2012). Telecom Companies Suffer Over N1bn in Losses to Boko Haram Attacks. Thisday, September 11

Ojione, O.C. (2007). The Implementation of the African Growth and Opportunity Act (AGOA) by Beneficiary (African) States. Nigerian Journal of International Affairs. 33 (1): 65-81

Omoruyi, O. (2001). The Nigerian-US Military Pact, Fine Prints Recipe for Danger; Whither National Assembly. http://nigeriaworld.com/ feature/publication/omoruyi/070201.html, retrieved 3/4/13

Omotola, S.J. (2003). Combating International Terrorism: Possibilities and Limitations. Nigerian Journal of International Affairs. 29 (1 and 2): $282-302$

Onuoha, J.I. (2005). The United States and the Road to Peace in the Middle East. University of Nigeria Journal of Political Economy. 1 (1): $184-201$

Onuoha, J.I. (2008). Beyond Diplomacy: Contemporary Issues in International Relations. Nsukka: Great AP Express Publishers

Oritsejafor, A. (2012). How US Congress, CAN Leader, Blasted US Government Over Boko Haram Stance. http://nigeriavillagesquare. 
com/newsflash/how-us-congress-can-leader-blasted-us-govt-over-boko-haram-stance.html, retrieved 1/05/13

Oteboh, M. (2013). Wanted: U.S. Places $\$ 7$ Million Bounty on Boko Haram Leader, Shekau. http://premiumtimeng.com/news/137459wanted... retrieved, $31 / 7 / 2013$

Oyedele, D. and Olugbode, M. (2012). Nigeria: Boko Haram-US Raises Concern Over Extra-Judicial Killings. Thisday, November 16

Peacock, S. (2012). Obama: Slaughter of Christians a Misunderstanding. http://mobile.wnd.com/2012/05/obama-slaughter-of-christiansa-misunderstanding, retrieved on 13/05/2013

Pillar, P.R. (2001). Terrorism and US Foreign Policy. Washington DC: Brookings Institution Press Premium Times (2013). U.S. Foreign Investment in Nigeria Increases from $\$ 5.2 \mathrm{bn}$ to $\$ 8 \mathrm{bn}$. http://premiumtimesng.com/business/132 317...html, retrieved, 4/7/2013

Sanda, J.G. (2010). Nigeria's Global Role in Peacekeeping: from the Congo through Lebanon to Bosnia Herzegovina. In A.M. Jega and J.W. Farris (eds.) Nigeria at Fifty: Contributions to Peace, Democracy and Development. Abuja: the Shehu Musa Yar'Adua Foundation

Saliu, H.A. and Aremu, F.A. (2006). Continuity and Change in the US-Nigeria Relations: 1999-2005. Nigerian Journal of International Affairs. 31 (1): 133-154

Sani, S. (2011). Boko Haram: History, Ideas and Revolt. Journal of Constitutional Development. 11 (4): 1-16

Securipedia.Eu (2012). Economic Effects of Terrorism. http://securipedia.eu/mediawiki/index.php/Economi_effects_of_terrorism, retrieved, 5/7/2013

Smith, C. (2012). How to Resolve the Boko Haram Insurgency. Vanguard, August 12

The United States Department of State (2001). The Network of Terrorism

The United States Institute of Peace (2012). U.S.-Nigeria Binational Commission Convenes at USIP. http://www.usip.org/publication/usnigeria-binational-commission-convenes-usip, retrieved, 3/3/2013

The U.S. Department of State Report (2012). Bureau of African Affairs Fact Sheet. http://m.state.gov/md2836.htm, retrieved, 10/6/2012

Thewillnigeria.Com, (2013). NSA: Boko Haram, Kidnappers' Activities Impact on Climate Change. http:/thewillnigeria.com/general/ 20320. html, retrieved, 10/8/2013

Umoru, H. (2013). Boko Haram has Destroyed Nigeria's Reputation. Vanguard, August 13

United States Agency for International Development (USAID) Report (2012) retrieved from www. usaid. gov on 27/04/13

Uroko, C., Ajakaiye, A and Olaifa, B. (2012). Boko Haram Insurgence Crashes Property Prices in the North. http://www.businessday online.com/NG/index.php/news/76-hot-topic/34608..., retrieved 5/7/2013

US Department of State Information (2013) International Travel Information Report, http://travel.state.gov/travel/cis_pa_tw/tw/tw 5985.html, retrieved, 10/7/2013

Wikipedia the free encyclopedia (2013). World Tourism Rankings. http://en.m.wikipedia.org/wiki/world_tourism_rankings, retrieved, $9 / 7 / 2013$

WND Exclusive (2012). Obama: Slaughter of Christians a Misunderstanding. http://mobile.wnd.com/2012/05/obama-slaughter-ofchristians-a-misunderstanding, retrieved on 13/05/2013

World Bank (2010). International Tourism; Number of Arrivals. http://data.worldbank.org/indicator/ST.INT.ARVL, retrieved, 10/7/2013 